\title{
KUALITAS PELAYANAN KARTU TANDA PENDUDUK ELEKTRONIK DI KECAMATAN CISARUA KABUPATEN BOGOR
}

\author{
Siti Rahayu Septiany ${ }^{1}$, Beddy Iriawan Maksudi2 ${ }^{2}$ Irma Purnamasari ${ }^{3}$ \\ ${ }^{1}$ Jurusan Ilmu Administrasi Negara Fakultas Imu Sosial dan Ilmu Politik Universitas Djuanda, Jl.Tol \\ Ciawi No 1, Kotak Pos 35 Bogor 16770 \\ ${ }_{2}^{2}$ Jurusan Ilmu Administrasi Negara Fakultas Imu Sosial dan Ilmu Politik Universitas Djuanda, Jl.Tol \\ Ciawi No 1, Kotak Pos 35 Bogor 16770 \\ ${ }^{3}$ Jurusan Ilmu Administrasi Negara Fakultas Imu Sosial dan Ilmu Politik Universitas Djuanda, Jl.Tol \\ Ciawi No 1, Kotak Pos 35 Bogor 16770
}

(Diterima oleh Dewan Redaksi: 01-02-2016)

(Dipublikasikan oleh Dewan Redaksi: 01-04-2016)

\begin{abstract}
SITI RAHAYU SEPTIANY, State Administration Study Program, Faculty of Social and Political Sciences, Djuanda University, Bogor, 2016, Service Quality of Electronic Identity Card in District Cisarua, Bogor Regency, Advisor I: Drs. BeddyIriawan Maksudi, M.Sc., Advisor II: Irma Purnamasari, S. Sos., M.Sc.

Various community responses tend to suggest that different types of public services suffered a setback which is mainly marked by numerous irregularities in the public service. Systems and procedures are complicated, and human resources were slow in providing the service, expensive, closed, and discriminatory and cultured not serve, but served also an aspect of public service spotlight, especially in terms of population administration one of them in the service of making electronic ID card.

The research objective is to know the quality of the electronic ID card service in District Cisarua, Bogor regency.

The theory that used to analyze the quality of service is a theory proposed by Parasuraman in Harbani Pasolong (2013) which has five dimensions of service quality to be able to successfully include the dimensions of tangible, reliability, responsiveness, assurance, empathy. The five dimensions above should be implemented fully for one another have relevance.

This research used descriptive quantitative method by using questionnaires as the main instrument to data collect.

These results indicate that the quality of the electronic ID card service in District Cisarua, Bogor regency according to respondents of employees included in the criteria for the interpretation of Good, while according to the respondents community service quality Electronic Identity Card in District Cisarua, Bogor regency included in the criteria Pretty Good. It is explained that the completion of this electronic ID card service can't be resolved quickly due to the completion of this electronic ID cards involve other agencies, namely the Department of Population and Civil Registration in Bogor district is not authorized for card printing and database processing.

Suggestions from this study recommend that the government give them the authority to process the district population database that can handle an error in the electronic ID card identity. Then the district should continue to strive to conduct socialization to the village office of each region, with emphasis to the village to mobilize RW and RT convey any information which would have informed to the public;
\end{abstract}

Keywords: Service Quality of electronic ID cards 


\begin{abstract}
ABSTRAK
SITI RAHAYU SEPTIANY, Program Studi Administrasi Negara, Fakultas Ilmu Sosial dan Ilmu Politik, Universitas Djuanda Bogor, 2016, Kualitas Pelayanan Kartu Tanda Penduduk Elektronik di Kecamatan Cisarua Kabupaten Bogor, Pembimbing I : Drs. Beddy Iriawan Maksudi, M.Si., Pembimbing II : Irma Purnamasari, S.Sos., M.Si.

Berbagai tanggapan masyarakat cenderung menunjukkan bahwa berbagai jenis pelayanan publik mengalami kemunduran yang utamanya ditandai dengan banyaknya penyimpangan dalam layanan publik tersebut. Sistem dan prosedur pelayanan yang berbelit-belit, dan sumber daya manusia yang lamban dalam memberikan pelayanan, mahal, tertutup, dan diskriminatif serta berbudaya bukan melayani melainkan dilayani juga merupakan aspek layanan publik yang banyak disoroti, terutama dalam hal administrasi kependudukan salah satunya dalam pelayanan pembuatan KTP elektronik.

Tujuan Penelitian untuk mengetahui kualitas pelayanan KTP-el di Kecamatan Cisarua Kabupaten Bogor.

Teori yang digunakan dalam menganalisis kualitas pelayanan adalah teori yang dikemukakan oleh Parasuraman dalam Harbani Pasolong (2013) dimana kualitas pelayanan memiliki 5 dimensi untuk dapat berhasil diantaranya dimensi tangible, reliability, responsiveness, assurance, empathy. Ke lima dimensi diatas harus dilaksanakan secara menyeluruh karena satu dengan yang lainnya memiliki keterkaitan.

Metode Penelitian yang digunakan dalam penelitian ini adalah metode deskriptif kuantitatif dengan menggunakan kuesioner/angket sebagai instrumen utama untuk mengumpulkan data.

Hasil penelitian ini menunjukkan bahwa kualitas pelayanan KTP elektronik di Kecamatan Cisarua Kabupaten Bogor menurut responden pegawai termasuk dalam kriteria penafsiran Baik, sedangkan menurut responden masyarakat kualitas pelayanan KTP Elektronik di Kecamatan Cisarua Kabupaten Bogor termasuk dalam kriteria Cukup Baik. Hal ini dijelaskan bahwa penyelesaian pelayanan KTP elektronik ini belum bisa diselesaikan secara cepat dikarenakan penyelesaian KTP elektronik ini melibatkan pihak instansi lain yaitu Dinas Kependudukan dan Pencataan Sipil Kabupaten Bogor dan pihak kecamatan tidak diberi kewenangan untuk pencetakan kartu serta mengolah database.

Saran dari hasil penelitian ini diantaranya Sebaiknya pemerintah memberikan kewenangan dalam mengolah database kependudukan agar pihak kecamatan dapat menangani adanya kesalahan dalam identitas KTP elektronik. Kemudian seharusnya pihak kecamatan terus berusaha untuk mengadakan sosialisasi ke Kantor Desa masing-masing wilayah, dengan menekankan kepada pihak desa untuk mengerahkan RW dan RT menyampaikan segala informasi yang memang seharusnya disampakan ke masyarakat;
\end{abstract}

Kata Kunci : Kualitas Pelayanan KTP elektroni

Siti Rahayu Septiany, 2016. Kualitas Pelayanan Kartu Tanda Penduduk Elektronik Di Kecamatan Cisarua Kabupaten Bogor. 


\section{PENDAHULUAN}

Berdasarkan Undang-undang nomor 11 tahun 2008 tentang informasi dan transaksi elektronik disebutkan bahwa pembangunan nasional adalah suatu proses yang berkelanjutan yang harus senantiasa tanggap terhadap berbagai dinamika yang terjadi di masyarakat, terkait hal tersebut dinamika pelaksanaan pembangunan dan perkembangan teknologi telah merubah peranan dan fungsi pemerintah. Perubahan tersebut seperti, pada awalnya segala kegiatan administrasi pemerintahan dilakukan secara manual, salah satu contohnya KTP menjadi KTP Elektronik.

Pemerintah juga ditempatkan untuk menjalankan fungsi disamping sebagai abdi negara, juga sebagai abdi masyarakat (UU Nomor 8 Tahun 1974). Dalam konteks ini, kegiatan pelayanan umum merupakan perwujudan dan penjabaran dari tugas dan fungsi aparatur pemerintah dalam rangka penyelenggaraan tugas-tugas umum pemerintahan maupun pembangunan. (Nurul Martila, 2011:1)

Dengan pemahaman tersebut, lingkup pengertian pelayanan publik kemudian secara formal dirumuskan sebagaimana dituangkan dalam Undangundang Nomor 25 Tahun 2009 Bab I pada pasal 1, yakni pelayanan publik adalah kegiatan atau rangkaian kegiatan dalam rangka pemenuhan kebutuhan pelayanan sesuai dengan peraturan perundangundangan bagi setiap warga negara dan penduduk atas barang, jasa dan/atau pelayanan administratif yang disediakan oleh penyelenggara pelayanan publik.

Perbaikan pelayanan publik di era reformasi ini merupakan harapan seluruh masyarakat, namun dalam perjalanan reformasi ternyata tidak mengalami perubahan yang signifikan. Berbagai tanggapan masyarakat justru cenderung menunjukkan bahwa berbagai jenis pelayanan publik mengalami kemunduran yang utamanya ditandai dengan banyaknya penyimpangan dalam layanan publik tersebut. Sistem dan prosedur pelayanan yang berbelit-belit, dan sumber daya manusia yang lamban dalam memberikan pelayanan, mahal, tertutup, dan diskriminatif serta berbudaya bukan melayani melainkan dilayani juga merupakan aspek layanan publik yang banyak disoroti. (Romadhana Alhadi Lubis, 2015:1)

Sesuai dengan Peraturan Daerah Kabupaten Bogor No. 24 Tahun 2008 kecamatan adalah perangkat daerah sebagai unsur pelaksana kewilayahan pada tingkat kecamatan dalam penyelenggaraan pemerintahan daerah. Jadi dalam hal ini pada dasarnya kecamatan merupakan penyedia layanan bagi warga negara dalam penyelenggaraan pembangunan, perekonomian, sosial, ketentraman dan ketertiban umum. Maka dari itu warga negara yang menerima pelayanan harus merasa puas karena memang merupakan hak yang dimiliki oleh setiap warga negara.

$$
\text { Salah satu dari tugas-tugas }
$$
pelayanan umum aparatur kecamatan adalah sistem administrasi kependudukan, yang dalam pelaksanaannya berkaitan erat dengan hak sipil atau hak perdata penduduk. Menurut Undang-undang No. 24 Tahun 2013 data kependudukan adalah data perseorangan dan/atau data agregat yang terstruktur sebagai hasil dari kegiatan Pendaftaran Penduduk dan Pencatatan Sipil. Kemudian pendaftaran penduduk adalah perncatatan biodata penduduk, pencatatan dan pendataan penduduk rentan administrasi kependudukan berupa kartu identitas atau surat keterangan kependudukan. Kartu identitas penduduk disebut Kartu Tanda Penduduk atau KTP pengertian Kartu Tanda Penduduk menurut Undang-undang No. 23 tahun 2006 adalah identitas resmi penduduk sebagai bukti diri yang diterbitkan oleh instansi pelaksana yang berlaku diseluruh wilayah Negara Kesatuan Republik Indonesia.

Sesuai dengan perkembangan teknologi pada saat ini, pembuatan maupun perpanjangan KTP di Indonesia sudah berubah dari KTP konvensional menjadi 
KTP elektronik (KTP-el), menurut Undangundang Nomor 24 tahun 2013 KTP elektronik (KTP-el) adalah Kartu Tanda Penduduk yang dilengkapi cip yang merupakan identitas resmi penduduk sebagai bukti diri yang diterbitkan oleh instansi pelaksana. Berikut adalah data KTP-el tahun 2015 yang diperoleh penulis dari kantor Kecamatan Cisarua. pembuatan KTP-el yang lebih dari 3 bulan;

d. Lambatnya penyampaian informasi mengenai sosialisasi KTP-el disebabkan fungsi RT yang tidak berjalan semestinya;

e. Sistem pengelolaan pengaduan yang belum tertangani secara cepat, seperti adanya kesalahan data yang tertera di KTP elektronik.

Tabel 1

Data KTP-el Kecamatan Cisarua

\begin{tabular}{|c|c|c|c|c|c|}
\hline \multirow[b]{2}{*}{$\begin{array}{l}\text { N } \\
\text { o. }\end{array}$} & \multirow[b]{2}{*}{$\begin{array}{c}\text { Desa/ } \\
\text { Kelurahan }\end{array}$} & \multicolumn{4}{|c|}{ Kartu Tanda Penduduk } \\
\hline & & Wajib & Memiliki & Belum & $\begin{array}{c}\text { Pers } \\
\text { entas } \\
\text { e }\end{array}$ \\
\hline 1 & Tugu Selatan & 12.547 & 11.351 & 1.196 & $90 \%$ \\
\hline 2 & Tugu Utara & 7.765 & 7.614 & 151 & $98 \%$ \\
\hline 3 & Cibeureum & 10.861 & 7.752 & 3.109 & $71 \%$ \\
\hline 4 & Batu Layang & 6.309 & 5.589 & 720 & $89 \%$ \\
\hline 5 & Cisarua & 6.355 & 6.192 & 163 & $97 \%$ \\
\hline 6 & Citeko & 8.777 & 7.090 & 1.687 & $81 \%$ \\
\hline 7 & Jogjogan & 5.678 & 5.607 & 71 & $99 \%$ \\
\hline 8 & Leuwimalang & 5.385 & 5.325 & 60 & $99 \%$ \\
\hline 9 & Cilember & 6.992 & 6.866 & 126 & $98 \%$ \\
\hline $\begin{array}{l}1 \\
0\end{array}$ & Коро & 10.799 & 8.352 & 2.447 & $77 \%$ \\
\hline & Jumlah & 81.468 & 71.738 & 9.730 & $88 \%$ \\
\hline
\end{tabular}

Sumber : Kantor Kecamatan Cisarua, 2015

Dengan demikian bahwa kondisi mengenai pelayanan pembuatan KTP elektronik di Kantor Kecamatan Cisarua sejauh ini masih belum maksimal, berdasarkan pengamatan dan wawancara diantaranya sebagai berikut:

a. Peralatan yang digunakan oleh aparatur kecamatan memang sudah termasuk modern seperti perangkat komputer dan printer, namun peralatan tersebut terbatas jumlahnya. Seperti di Front Office hanya terdapat komputer tetapi tidak ada printer, jadi ketika aparatur harus melakukan kegiatan administrasi contohnya membuat surat harus ke unit kerja lain. Kemudian alat perekaman sering mengalami gangguan teknis. Hal ini juga membuat pelayanan menjadi lambat;

b. Jaringan sering offline;

c. Aparatur Kecamatan Cisarua belum mampu memenuhi secara optimal dalam hal melayani sesuai waktu yang dijanjikan hal ini dibuktikan dalam
Berdasarkan paparan di atas maka penulis menganggap hal ini penting untuk dikaji lebih lanjut dengan harapan untuk lebih mengetahui dan memahami mengenai kualitas pelayanan terutama dalam pelayanan KTP-el yang terdapat beberapa masalah, sehingga pada penulisan ini penulis tertarik untuk memilih judul "Kualitas Pelayanan Kartu Tanda Penduduk Elektronik di Kecamatan Cisarua Kabupaten Bogor".

\section{MATERI DAN METODE}

Kualitas dapat dihasilkan dengan berbagai cara maupun sumber informasi yang berbeda. Parasuraman dalam Herbani Pasolong (2013:207) membagi indikator kualitas pelayanan yaitu:

1. Tangible adalah indikator yang mencakup kondisi fisik, peralatan serta penampilan pegawai dan fasilitasfasilitas lain yang dimiliki provider.

2. Reliability adalah indikator yang menunjukkan kemampuan untuk menyelenggarakan pelayanan secara akurat dan handal, dapat dipercaya, bertanggungjawab atas apa yang dijadikan, tidak pernah memberikan janji yang berlebihan dan selalu menepati janjinya;

3. Responsiveness adalah indikator yang menunjukkan bahwa keinginan untuk membantu pelanggan dan memberikan pelayanan yang cepat dan tepat, kerelaan untuk melayani pelanggan dan 
menyelenggarakan pelayanan secara ikhlas;

4. Assurance adalah indikator yang mencakup 4 hal yaitu Competency, Courtesy, Credibility dan Cecurity;

5. Empathy, indikator ini terdiri dari 3 hal yaitu Accessbility, Communication skill, dan Understanding the customer.

Metode Penelitian yang digunakan dalam penelitian ini adalah metode deskriptif kuantitatif. Dalam hal ini peneliti mencoba mengemukakan maupun menjelaskan apa yang ditemukan dilapangan dengan cara deskriptif.

Berdasarkan hal tersebut maka metode penelitian deskriptif yang dimaksud dalam penelitian ini adalah mengenai masalah kualitas pelayanan dalam pembuatan KTP elektronik di Kecamatan Cisarua Kabupaten Bogor, Sedangkan pendekatan yang digunakan dalam penelitian ini pendekatan kuantitatif yaitu data penelitian berupa angka-angka dan analisis menggunakan statistik. . (Sugiyono 2011:7)

\section{TEKNIK \\ PENARIKAN SAMPEL Populasi dan Sampel}

Di dalam penelitian ini yang dijadikan sebagai populasi adalah Pegawai Kantor Kecamatan Cisarua dan seluruh masyarakat yang sudah memiliki KTP Elektronik.

\begin{tabular}{|c|c|c|}
\multicolumn{3}{c}{ Tabel 2 } \\
\multicolumn{3}{|c|}{ Populasi } \\
\hline No. & \multicolumn{1}{|c|}{ Unsur } & Populasi \\
\hline 1 & Pegawai & 22 \\
\hline 2 & Masyarakat & \\
\cline { 2 - 3 } & Ds. Tugsel & 11.351 \\
\cline { 2 - 3 } & Ds. Cilember & 6.866 \\
\cline { 2 - 3 } & Ds. Leuwimalang & 5.325 \\
\hline & Jumlah & $\mathbf{2 3 . 5 6 4}$ \\
\hline
\end{tabular}

Dalam penelitian ini menggunakan dua teknik sampling yaitu teknik sampling jenuh untuk sampel pegawai dan teknik sampling purposive untuk sampel masyarakat.
Untuk sampel pegawai diambil dari jumlah populasi yaitu 22 orang. Sedangkan untuk sampel penduduk dalam penelitian ini peneliti mengambil sampel dari 3 desa berdasarkan jumlah data penduduk yang sudah memiliki KTP-el yakni jumlah penduduk paling banyak yaitu Desa Tugu Selatan, jumlah penduduk sedang yaitu Desa Cilember dan jumlah penduduk yang paling sedikit yaitu Desa Leuwimalang. Seluruh sampel masyarakat berjumlah 27 orang.

\section{JENIS DAN TEKNIK PENGUMPULAN DATA}

Untuk mendapatkan data yang relevan dan sesuai dengan kebutuhan yang berkaitan dengan penelitian, maka metode pengumpulan data yang diguanakan adalah sebagai berikut :

1. Interview (Wawancara)

Penulis melakukan interview atau wawancara dengan Kasi. Pemerintahan, Pelaksana Pemerintahan, bagian pelayanan dan dengan beberapa masyarakat mengenai pelayanan KTP elektronik di Kecamatan Cisarua Kabupaten Bogor.

2. Kuesioner (Angket)

Kuesioner atau angket berupa pernyataan yang berjumlah 16. Sampel dimintai untuk mengisi pernyataan tersebut dengan cara memberikan tanda ceklis $(\sqrt{ })$ pada salah satu jawaban.

3. Observasi (Penelitian Lapangan)

Observasi dilakukan di Kantor Kecamatan Cisarua serta dengan cara penulis mendatangi ke 3 desa yaitu Tugu Selatan, Cilember dan Leuwimalang.

4. Studi Kepustakaan

Dalam penelitian ini penulis menggunakan banyak referensi dari buku-buku tentang kualitas pelayanan, pemerintahan dan contoh-contoh penelitian yang pernah dilakukan oleh orang lain tentang kualitas pelayanan ini. 
Dalam penelitian ini penulis menggunakan skala likert, skala ini mewakili suatu negatif tertentu yang bergerak dari tingkat paling positif ke tingkat paling negatif dan kemudian diberi angka atau nilai (scoring).

Diharapkan dalam penelitian ini diperoleh data yang seakurat mungkin guna pemaparan hasil penelitian secara lengkap dan jelas, serta dapat mengungkap apa yang ada pada realitanya.

\section{TEKNIK ANALISIS DATA}

Dalam penelitian deskriptif kuantitatif Analisis data merupakan kegiatan setelah data dari seluruh responden atau sumber data lain terkumpul. Kegiatan dalam analisa data adalah mengelompokkan data berdasarkan variabel dan jenis responden, mentabulasi data berdasarkan variabel dari seluruh responden, menyajikan data tiap variabel yang diteliti, melakukan perhitungan untuk menjawab rumusan masalah.

Teknik analisa data dalam penelitian kuantitatif ini, data yang diperoleh dari kuesioner yang diisi reponden di entry dengan menggunakan excel, untuk mengetahui tabulasi frekuensi.

Deskriptif digunakan untuk
menganalisa data dengan cara
data yang telah terkumpul sebagaimana adanya tanpa bermaksud membuat kesimpulan yang berlaku untuk umum atau generalisasi.

Untuk mempermudah Analisis data dan penarikan kesimpulan maka disamping menggunakan perhitungan persentase juga dilakukan dengan menggunakan statistik sederhana yaitu mentransformasikan data kualitatif menjadi data kuantitatif. Cara ini biasanya dengan menggunakan perhitungan Weight Mean Score (MWS) yaitu dilakukan pembobotan untuk setiap jawaban pilihan.

Dengan pemberian skor tersebut, maka akan diperoleh variasi jawaban yang bergerak 1-5, karena itu interval antara satu kriteria dengan kriteria lainnya yang diperoleh angka sebesar 0,8. Angka ini diperoleh setelah adanya pengurangan dari nilai tertinggi dikurangi nilai terendah dan dibagi banyaknya alternatif jawaban. Untuk menentukan kriteria penilaian harus dihitung terlebih dahulu interval antara satu kriteria dengan kriteria yang lain dengan menggunakan skala Likert sebagai berikut :

$$
\begin{aligned}
I= & \frac{S K T-S K R}{V} \\
& \text { Keterangan : } \\
& \mathrm{I} \quad=\text { Interval } \\
& \text { SKT = Skor Tertinggi } \\
\mathrm{V} & =\text { Jumlah } \\
I & =\frac{5-1}{5}=0,8
\end{aligned}
$$

Hasil penghitungan dari 0,8 dijadikan patokan untuk memperoleh kriteria penilaian, dari ketentuan diatas, maka kriteria penilaian sebagai berikut :

\section{Tabel 3}

\section{Kriteria Penilaian}

\begin{tabular}{|c|c|c|}
\hline NO. & Skor & Kriteria \\
\hline 1. & $4,24-5,04$ & Sangat Baik \\
\hline 2. & $3,43-4,23$ & Baik \\
\hline 3. & $2,62-3,42$ & Cukup Baik \\
\hline 4. & $1,81-2,61$ & Kurang Baik \\
\hline 5. & $1-1,80$ & Tidak Baik \\
\hline
\end{tabular}

Menurut Bakri Siregar (1981 : 20) data yang diperolah dari lapangan lalu dioleh berdasarkan jawaban responden melalui angket dengan menggunakan rumus WMS :

$$
\begin{aligned}
& M=\frac{\Sigma f(x)}{n} \\
& \text { Dimana : } \\
& \mathrm{M}=\text { Perolehan angka penafsiran } \\
& \mathrm{N}=\text { Jumlah Responden } \\
& f=\text { Frekuensi Jawaban } \\
& x=\text { Pembobotan } \\
& \Sigma=\text { Penjumlahan }
\end{aligned}
$$

\section{HASIL DAN PEMBAHASAN}

Berdasarkan hasil penelitian, Analisis Kualitas Pelayanan Kartu Tanda Penduduk Elektronik di Kecamatan Cisarua Kabupaten Bogor. Menunjukkan Kriteria 
Baik, yang dapat dilihat pada tabel dibawah ini.

Tabel 4

\begin{tabular}{|c|c|c|c|c|}
\hline \multirow{2}{*}{ Dimensi } & \multicolumn{2}{|c|}{$\begin{array}{c}\text { Angka Penafsiran } \\
\text { (M) }\end{array}$} & \multirow[t]{2}{*}{$\begin{array}{l}\text { Nilai } \\
\text { Rata } \\
\text {-rata }\end{array}$} & \multirow{2}{*}{$\begin{array}{l}\text { Kriter } \\
\text { ia } \\
\text { Penaf } \\
\text { siran }\end{array}$} \\
\hline & $\begin{array}{c}\text { Pegawa } \\
\text { i }\end{array}$ & $\begin{array}{c}\text { Masyara } \\
\text { kat }\end{array}$ & & \\
\hline Tangible & 3,6 & 3,6 & 3,6 & Baik \\
\hline Reliability & 3,7 & 3,2 & $\begin{array}{r}3,4 \\
5 \\
\end{array}$ & Baik \\
\hline Responsiveness & 3,9 & 3,4 & $\begin{array}{r}3,6 \\
5 \\
\end{array}$ & Baik \\
\hline Assurance & 4,1 & 3,3 & 3,7 & Baik \\
\hline Empathy & 3,78 & 3,46 & $\begin{array}{r}3,6 \\
2 \\
\end{array}$ & Baik \\
\hline Jumlah & 19,08 & 16,96 & & \\
\hline $\begin{array}{c}\begin{array}{c}\text { Jumlah Rata- } \\
\text { rata } \\
\sum \text { Skor }\end{array} \\
\text { Jumlah Dimensi }\end{array}$ & $\begin{array}{l}19,08= \\
\frac{3,8}{5}\end{array}$ & $\begin{array}{l}16,96 \\
=3,39 \\
5\end{array}$ & & \\
\hline $\begin{array}{l}\text { Jumlah Rata- } \\
\text { rata kedua } \\
\text { responden }\end{array}$ & & 3,59 & & Baik \\
\hline
\end{tabular}

Sumber : Hasil Penelitian 2016

Dari tabel rekapitulasi jawaban responden terhadap variabel Kualitas Pelayanan dalam Pembuatan KTP elektronik pada Kecamatan Cisarua Kabupaten Bogor. Menunjukkan Rekapitulasi Jawaban Responden Terhadap Variabel Kualitas Pelayanan KTP elektronik di Kecamatan Cisarua Kabupaten Bogor diperoleh skor rata-rata sebesar 3,59 yang menurut penafsiran berada pada kategori BAIK.

Kualitas pelayanan dalam penelitian ini menggunakan teori dari Harbani Pasolong (2013) yaitu Tangible, Reliability, Responsiveness, Assurance dan Empathy. Masing-masing dimensi terdapat indikator diuraikan sebagai berikut.

1) Dimensi Tangible

a. Ruang tunggu yang nyaman

Kantor Kecamatan Cisarua Kabupaten Bogor telah mengalami perubahan tata ruang atau renovasi gedung sejak tahun 2015, dengan demikian Kantor Kecamatan Cisarua telah menyediakan ruang tunggu yang nyaman, bersih, tertata rapih, tersedianya fasilitas pelayanan yang disebut front office.

b. Peralatan yang Modern

Hasil dari perhitungan kuesioner pegawai dan masyarakat menunjukkan bahwa peralatan yang modern telah dimiliki oleh Kantor Kecamatan Cisarua, namun masih terbatas jumlahnya.

2) Dimensi Reliability

a. Aparatur mampu melayani dengan benar

Berdasarkan hasil dari wawancara antara pihak kecamatan dan pihak warga mengatakan hal yang sama bahwa aparatur mampu melayani dengan benar, hal ini dibuktikan dengan usaha meminimalisir kesalahan dalam proses pembuatan KTP elektronik dengan diperiksa kelengkapannya.

b. Aparatur sudah memberikan pelayanan KTP elektronik sesuai Standar Operasional Prosedur (SOP)

Berdasarkan hasil wawancara dengan pegawai dan masyarakat menyatakan bahwa dalam memberikan pelayanan sudah sesuai dengan Standar Operasional Prosedur (SOP). Dimulai dari pemohon meminta informasi persyaratan ke loket informasi atau langsung mengisi, menyerahkan Formulir dan persyaratan, persyaratan pembuatan KTP-el di Kecamatan Cisarua yaitu (1) Surat Pengantar dari Kelurahan atau Desa; (2) Fotokopi Kartu Keluarga; (3) Foto Ukuran 4x6 1 Lembar; (4) KTP yang lama. Setelah itu cek persyaratan jika belum lengkap ditolak dan jika lengkap diberi tanda terima berkas lengkap kemudian berkas diserahkan ke bagian proses dan pemohon diminta untuk menunggu antrian proses perekaman data diri. 
Setelah melalui proses perekaman data diri tanda tangan berkas kelengkapan oleh Camat dan pemohon diberi KTP sementara serta pencetakan KTP di DISDUKCAPIL.

c. Pegawai terhadap Adanya Sistem Pengelolaan Pengaduan Pelayanan KTP Elektronik

Pengelolaan pengaduan sebagian besar ditangani oleh pihak DISDUKCAPIL, pihak kecamatan hanya melaporkan dengan menggunakan form F-105 yaitu Surat Pernyataan Perubahan Data Kependudukan. Form ini digunakan untuk memperbaiki data yang salah.

d. Kemampuan dalam Menyelesaikan Pelayanan dengan Tepat Waktu

Kemampuan dalam menyelesaikan pembuatan KTP elektronik memang tidak bisa dengan waktu yang cepat disebabkan proses pencetakan KTP elektronik dilakukan di DISDUKCAPIL dan database masih banyak yang terdata ganda disebabkan seringnya jaringan offline, sementara tindak lanjut dari pihak DISDUKCAPIL lambat, sehingga proses penyelesaian KTP elektronik jadi lambat pula.

\section{3) Dimensi Responsiveness}

a. Aparatur selalu membantu masyarakat dalam memberikan informasi yang benar

Menurut beberapa aparatur mengakui bahwa informasi yang disampaikan kepada masyarakat selalu berdasarkan arahan dari atasan. Sementara menurut pendapat masyarakat, masyarakat menerima informasi terkadang lambat, sehingga kegiatan dilakukan secara mendadak hal ini disebabkan pihak kecamatan memberikan informasi melalui kepala desa atau lurah kemudian baru informasi disampaikan ke RW dan RT, dan RT yang menyampaikan informasi kepada Masyarakat, hal ini juga diterangkan oleh aparatur kecamatan bahwa sampai pada saat ini fungsi RT tidak berjalan dengan semestinya.

b. Standar Pelayanan Minimal (SPM) dalam Pelayanan KTP Elektronik Kecamatan memiliki Standar Pelayanan Minimal (SPM) sesuai dengan Surat Keputusan Bupati Bogor Nomor 474/91-Disduk tentang penunjukan petugas pengolahan database kependudukan pada Kecamatan di Kabupaten Bogor dan Peraturan Presiden Republik Indonesia Nomor 25 Tahun 2008 Pasal 11-14, pelayanan dilakukan sesuai dengan petunjuk yang tertera di SK peraturan tersebut. Kemudian responden masyarakatpun menyatakan bahwa standar pelayanan yang diberikan oleh aparatur sudah baik.

c. Cepat Tanggap dalam Hal Pelayanan Hasil dari kuesioner pegawai maupun masyarakat menunjukkan baik, artinya pelayanan dalam proses pembuatan KTP elektronik (hanya sampai proses perekaman) baik pembuatan awal maupun ada perbaikan ditanggapi dengan cepat.

d. Tidak Pernah Merasa Sibuk Untuk Memenuhi Kebutuhan Masyarakat

Berdasarkan hasil dari kuesioner dan didukung oleh observasi peneliti, bahwa aparatur selalu siap untuk memenuhi kebutuhan masyarakat dalam hal 
pelayanan terutama dalam pembuatan KTP elektronik.

4) Dimensi Assurance

a. Rasa aman dalam pelayanan

Sebagian masyarakat belum sepenuhnya merasa aman dalam hal pelayanan seperti keluhan kesalahan identitas belum ada tindak lanjut yang serius sehingga ada beberapa masyarakat yang KTPnya sampai pada saat ini belum juga terselesaikan.

b. Memiliki Pengetahuan untuk Menjawab Pertanyaan Pelanggan

Pengetahuan dalam hal melayani adalah salah satu faktor yang mempengaruhi dalam meningkatkan kualitas pelayanan, aparatur telah mengikuti pelatihan tentang pembuatan atau proses KTP elektronik di DISDUKCAPIL. Kemudian menurut masyarakatpun aparatur telah handal dalam menjawab pertanyaan tentang pelayanan pembuatan KTP ini.

c. Jujur dalam Memberikan Pelayanan Aparatur selalu dituntut untuk jujur dalam memberikan pelayanan terutama dalam hal pembiyaan pembuatan KTP elektronik tidak ada biaya sama sekali atau gratis, tetapi ada juga masyarakat yang mengatakan bahwa dalam pembuatan KTP elektronik, aparatur menerima imbalan sukarela dari masyarakat pembuat KTP elektronik. Kemudian penyampaian informasi jangka waktu selesainya proses pembuatan sampai percetakan KTP elektronik, walaupun prosesnya lama tetapi tetap disampaikan oleh aparatur kepada masyarakat agar timbul pengertian dari masyarakat.

5) Dimensi Empathy

a. Keramahan aparatur dalam memberikan pelayanan

Keramahan aparatur dalam memberikan pelayanan sudah baik, hal ini dibuktikan dari hasil kuesioner responden pegawai dan masyarakat, kemudian dijelaskan oleh Kasi. Pemerintahan bahwa aparatur di Kecamatan Cisarua dituntut untuk selalu bersikap ramah dalam memberikan pelayanan kepada masyarakat.

b. Pegawai terhadap Mampu Berkomunikasi yang Baik dengan Masyarakat

Aparatur mampu

berkomunikasi yang baik dengan masyarakat melalui penyampaian informasi yang jelas dan akurat sehingga masyarakat tidak kesulitan dalam menerima informasi.

c. Mampu Menjalin Hubungan yang Baik dengan Masyarakat

Menjalin hubungan yang baik dengan masyarakat seperti contohnya melayani dengan benar agar masyarakat merasa nyaman dan akhirnya mempunyai hubungan yang baik, kemudian mengadakan pertemuan secara rutin setiap hari Rabu di Kantor Desa secara bergiliran dalam rangka memberikan sosialisasi mengenai tertib administrasi kependudukan kepada RW dan RT serta tokoh masyarakat masing-masing wilayah. 


\section{KESIMPULAN DAN IMPLIKASI}

Berdasarkan pembahasan mengenai kualitas pelayanan KTP elektronik di Kecamatan Cisarua Kabupaten Bogor, maka dapat diambil kesimpulan sebagai berikut:

1) Kualitas pelayanan menurut responden pegawai Kecamatan Cisarua Kabupaten Bogor telah dilaksanakan dengan Baik, hal tersebut ditunjukkan oleh hasil responden dan wawancara dengan Kasi. Pemerintahan serta para aparatur dengan angka penafsiran 3,8. Dengan melihat hasil tersebut kualitas pelayanan yang diberikan oleh aparatur pihak Kecamatan Cisarua telah berusaha untuk memberikan pelayanan yang terbaik, namun dalam hal ini pihak kecamatan memang tidak bisa menyelesaikan pelayanan khususnya dalam pembuatan KTP elektronik dengan tepat waktu disebabkan proses pencetakan KTP ini dilakukan di DISDUKCAPIL dan pihak kecamatan tidak diberikan kewenangan untuk mengolah database kependudukan.

Kualitas pelayanan menurut responden masyarakat Kecamatan Cisarua Kabupaten Bogor menghasilkan dengan kriteria Cukup Baik, hal tersebut ditunjukkan oleh hasil responden dan wawancara dengan masyarakat dengan angka penafsiran 3,39. Dengan melihat hasil tersebut kualitas pelayanan yang diberikan kepada masyarakat masih harus ditingkatkan lagi, karena menurut masyarakat kecepatan dalam menangani pelayanan KTP elektronik ini khususnya mengenai perbaikan kesalahan dalam identitas masih rendah.

\section{DAFTAR PUSTAKA}

A Anwar Prabu Mangkunegara, 2002. Manajemen Sumber Daya Manusia, Bandung : PT. Remaja Rosda Karya

Fandy Tjiptono, 1996. Manajemen Jasa, Yogyakarta: Penerbit Andi

Fandy Tjiptono, 2000. Manajemen jasa. Yogyakarta: Andi Offset.
Inu Kencana Safiie. 2009. Sistem Administrasi Negara Republik Indonesia (SANRI). Jakarta : Bumi Aksara

Kotler (2000). Manajemen Pemasaran Edisi Milenium. Jilid 1\&2. Jakarta : PT. Prenhalindo.

Kotler, 2009. Kotler, Philip. 2009. Manajemen Pemasaran. Jakarta : Erlangga

Pasolong, Harbani, 2008. Kepemimpinan Birokrasi. Bandung : Alfabeta

Reni Yanti Paelongan, 2015. Kualitas Layanan Pembuatan Akta Kelahiran pada Dinas Kependudukan dan Pencatatan Sipil Kabupaten Tana Toraja. Sulawesi : Universitas Hasanudin.

Soleh, Muhammad, 2005, Hubungan Persepsi Masyarakat Tentang Perilaku Birokrasi Terhadap Kualitas Pelayanan Publik. Tesis, Program Pascasarjana Program Studi Administrasi Negara Universitas Terbuka, Jakarta.

Sugiyono, 2011. Metode Penelitian Kuantitatif, Kualitatif dan R\&D. Bandung:Alfabeta.

Sugiyono 2012. Metode Penelitian Administrasi. Bandung : Alfabeta.

Tampubolon, Manahan, 2012. Perilaku Keorganisasian. Bogor : Ghalia Indonesia

Tjiptono, Fandy. 2012. Service Management Mewujudkan Layanan Prima. Yogyakarta: CV Andi Offset

Ummulchairi, 2012. Kualitas Pelayanan Akta Kelahiran di Dinas Kependudukan dan Catatan Sipil Kota Makassar. Sulawesi Selatan : Universitas Hasanudin.

Yuli Sudoso Hastono, 2008. Pelayanan Publik di Bandar Udara Polonia Medan,

Medan : Universitas Sumatera Utara.

Sumber Dokumen:

1) Undang-undang Nomor 11 Tahun 2008 tentang Informasi dan Transaksi Elektronik 
2) Undang-undang Nomor 23 Tahun 2006 tentang Administrasi Kependudukan

3) Undang-undang Nomor 24 Tahun 2013 tentang Perubahan Atas Undangundang Nomor 23 Tahun 2006 Tentang Administrasi Kependudukan

4) Undang-undang Nomor 25 Tahun 2009 tentang Pelayanan Publik

5) Peraturan Daerah Kabupaten Bogor Nomor 24 Tahun 2008 tentang Organisasi Dan Tata Kerja Kecamatan 